\title{
Chinese Angelica Polysaccharide (CAP) Alleviates LPS-Induced Inflammation and Apoptosis by Down-Regulating COX-1 in PC12 Cells
}

\author{
Yunjie Xie Haitao Zhang Yang Zhang Chong Wang Deyi Duan \\ Zheng Wang
}

Department of Neurosurgery, Jining First People's Hospital, Jining, China

\section{Key Words}

Spinal cord injury $\bullet$ Chinese angelica polysaccharide $\cdot$ apoptosis $\bullet$ inflammation $\bullet$ COX-1

\begin{abstract}
Abtract
Background/Aims: Chinese angelica polysaccharide (CAP) is the main effective ingredient of angelica sinensis and exerts anti-inflammatory and anti-apoptotic effects on many diseases. This study aimed to explore the pharmacological potential of CAP on spinal cord injury (SCI). Methods: PC12 cells were pretreated by CAP and were subjected to LPS. Transfection was performed to alter the expression of COX-1. Cell viability and apoptotic cell rate were measured by CCK-8 and flow cytometry respectively. qRT-PCR and western blot analysis were performed to assess the expression changes of pro-inflammatory cytokines, apoptosis-related factor and core kinases in PI3K/AKT pathway. Results: LPS stimulation induced significant cell damage in PC12 cells as cell viability was repressed, apoptosis was induced and the expression levels of IL-1 $\beta$, IL-6, IL-8, and TNF- $\alpha$ were increased. CAP pretreatment protected PC12 cells against LPS-induced cell damage. Meanwhile CAP treatment reduced the expression of COX-1 even in LPS-stimulated PC12 cells. More importantly, COX-1 overexpression abolished the protective effects of CAP on LPS-injured PC12 cells. Finally, Western blot analytical results showed that CAP activated PI3K/AKT pathway also in a COX-1-dependent manner. Conclusion: CAP exerted anti-apoptotic and anti-inflammatory effects on LPS-injured PC12 cells via downregulation of COX-1.

\section{Introduction}

Spinal cord injury (SCI) is a complex and devastating condition mainly induced by combined external forces axial compression and excessive lateral bending loading [1]. SCI leads to complex cellular and molecular interactions within the central nervous system (CNS) and results in severe neurological disorders [2]. SCI has a significant impact on the health, quality of life and life expectancy of human. It also carries a heavy economic burden, 
with considerable costs associated with primary care and loss of income [3]. Despite great efforts have been paid for improving the treatment of SCI, there still remains limitations [46].

The pathophysiology of SCI is characterized by an initial primary injury followed by a secondary phase of injury to the spinal cord. The secondary injury is mediated by multiple injury processes, including inflammation, free radical-induced cell death, and glutamate excitotoxicity [7]. Inflammatory response contributes a lot in the regulation of SCI pathogenesis, and seems to play a pivotal role in nerve injury and regenerative response [8]. In addition, inflammatory response may contribute to the apoptosis of neurons and oligodendrocytes as well as to the loss of neuronal function [9]. Therefore, anti-inflammation is thought to be critical for decrease of secondary degeneration and the functional deficit following SCI.

Angelica sinensis (Oliv.) Diels (family apiaceae) is a perennial umbelliferae herb that has a long history for use as a traditional Chinese medicine. It has been used for the treatment of various diseases, such as gynecological ailments, fatigue, anemia, and hypertension [10, 11]. The dried roots of angelica sinensis contain phthalides, polysaccharides, coumarin, and ferulate. Previous studies have shown that Chinese angelica polysaccharide (CAP) is the main effective ingredient of angelica sinensis and has effective functions in enhancing immunity, antivirus, anti-tumor, reducing blood glucose, antioxidant and etc $[10,12,13]$. What's more, it has been reported that CAP plays an important role in regulating inflammatory and apoptosis in SCI model $[14,15]$. However, its potential on SCI and the underlying mechanism need to be further explored.

Cyclooxygenases (COXs), known as prostaglandin $\mathrm{H}$ synthase, are key enzyme in the conversion of arachidonic acid into prostanoids and play important roles in the accommodation of inflammation, apoptosis, blood flow, immunomodulation, mitogenesis and secondary injury [16, 17]. COX-1 is constitutively expressed in the spinal cord [18]. Besides, COX-1 has been identified to be responsible for the immediate prostanoid response to inflammatory stimuli and its expression is persistently elevated following SCI in rat model [17]. These literatures suggested that selective inhibition of COX-1 might be a promoting strategy for treating SCI.

PC12 cells, which derive from a rat pheochromocytoma and possess neuron-like characteristics, have been applied for construction of useful model system in analyzing the neurological apoptosis [19]. SCI is a severe neurological disease, and mounting researches have used PC12 cells as important adjuncts and surrogates for studies of SCI in humans [20, 21]. Therefore, in this study, we investigated the protective effects of CAP against LPS-induced injuries in PC12 cells and explored its underlying molecular mechanisms. We found that CAP attenuated LPS-induced cell injuries in PC12 cells, evidenced by the decline of apoptosis and inflammation. In addition, our results implied that CAP conferred its protective effect through inhibition of COX-1.

\section{Materials and Methods}

\section{Cell culture and treatment}

PC12 cells were obtained from the American Type Culture Collection (ATCC; Rockville, MD, USA) and were used throughout the study. The cells were seeded in $75 \mathrm{~cm}^{2}$ flask in a concentration of $1 \times 10^{4}$ cells/ml and maintained in Dulbecco's modified Eagle Medium (DMEM; Sigma-Aldrich, St. Louis, MO, USA), containing 10\% fetal bovine serum (FBS; Hyclone, Logan, UT, USA), 5\% horse serum (Hyclone), $100 \mathrm{U} / \mathrm{ml}$ penicillin and $100 \mu \mathrm{g} / \mathrm{ml}$ streptomycin (Gibco, Life Technologies, Grand Island, NY) at $37^{\circ} \mathrm{C}$ in an humidified atmosphere containing $5 \% \mathrm{CO}_{2}$. Culture medium was changed every other day. Cells were treated with LPS in a series of concentration for $12 \mathrm{~h}$.

Prior to the treatment of LPS, the cells were incubated with different concentrations of CAP $(10,100$, and $200 \mu \mathrm{g} / \mathrm{ml}$ ) for $12 \mathrm{~h}$. CAP with purity of $98 \%$ was purchased from Yongye Bio-engineering Co., Ltd. (Shanghai, China).

\section{Transfection}

The full-length COX-1 sequences were constructed into pEX plasmids (Invitrogen, CA, USA) and were referred as to pEX-COX-1. The empty plasmid was used as its negative control (pEX). Cells were transfected with the special expression vector using Lipofectamine 2000 (Invitrogen). The stably transfected cells were 


\section{Cellular Physiology Cell Physiol Biochem 2018;49:1380-1388 and Biochemistry \begin{tabular}{l|l} 
DOI: 10.1159/000493415 & $\begin{array}{l}\text { C } 2018 \text { The Author(s). Published by S. Karger AG, Basel } \\
\text { www.karger.com/cpb }\end{array}$
\end{tabular} \\ Xie et al.: The Role of CAP in LPS-Injured PC12 Cells}

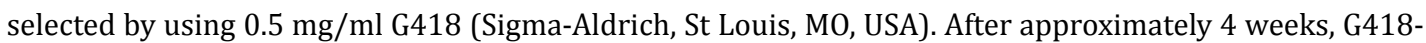
resistant cell clones were established.

\section{Quantitative real time RT-PCR analysis}

Total RNA was extracted using TRIzol reagent (Invitrogen), and was reverse transcribed into cDNA using a Reverse Transcription Kit (Takara, Dalian, China) according to the manufacturer's instructions. The expression levels of COX-1, IL-1 $\beta$, IL-6, IL-8, and TNF- $\alpha$ were measured by qRT-PCR by using the SYBR Green Master Mix (Takara) according to manufacturer's instruction. GAPDH level was detected for use in normalization. Data were calculated using the $2^{-\Delta \Delta \mathrm{Ct}}$ method.

\section{CCK-8 assay}

Cells were seeded in 96-well plates at a concentration of $1 \times 10^{4}$ cells/well for adherence. The cells were treated with CAP and/or LPS, and then cell viability was measured by CCK-8 Assay Kit (Dojindo, Kumamoto, Japan) according to the protocol. Briefly, treated cells were incubated with $10 \mu \mathrm{l} \mathrm{CCK-8} \mathrm{solution}$ for additional $1 \mathrm{~h}$ in the dark at $37^{\circ} \mathrm{C}$. Optical density was measured at $450 \mathrm{~nm}$ wavelength using a microplate reader (Bio-Rad Laboratories, Orlando, FL, USA).

\section{Apoptosis assay}

The cell apoptosis assay was performed with an Annexin V-FITC/PI Apoptosis Detection Kit (Beyotime Biotechnology, Shanghai, China). Briefly, treated cells were collected and washed with cold PBS. Cells were resuspended in $400 \mu \mathrm{l}$ binding buffer and subsequently incubated with a mixture of $5 \mu \mathrm{l}$ PI and $5 \mu \mathrm{l}$ Annexin V-FITC for $15 \mathrm{~min}$ at room temperature in the dark. Flow cytometry analysis was done by using a FACS can (Beckman Coulter, Fullerton, CA, USA). The data were analyzed by using FlowJo software (Tree Star Inc., Ashland, OR).

\section{Western blot}

Cell protein lysates were prepared using RIPA buffer (Beyotime Biotechnology) supplemented with protease inhibitors (Roche, Basel, Switzerland). The concentration of protein was quantified by the BCA Protein Assay Kit (Pierce, Rockford, IL, USA). $30 \mu \mathrm{g}$ denatured protein were loaded onto sodium dodecyl sulfate-polyacrylamide gel (SDS-PAGE), electrophoresed, and then transferred to polyvinylidene fluoride (PVDF) membranes (Millipore, Bedford, MA, USA). Membranes were blocked with 5\% BSA for $2 \mathrm{~h}$ at room temperature and then probed at $4^{\circ} \mathrm{C}$ overnight with primary antibodies. The primary antibodies: anti-Bax (\#5023), anti-Cleaved caspase 3 (\#9662), anti-Cleaved caspase-9 (\#20750), anti-Bcl-2 (\#4223), anti-IL$1 \beta$ (\#12703), anti-IL-6 (\#12153), anti-IL-8 (\#8921), anti-TNF- $\alpha$ (\#6945), anti-p-AKT (\#4060), anti-AKT (\#4685), anti-p-PI3K (\#4228), anti-PI3K (\#4249), anti-COX-1 (\#2750), anti- $\beta$-actin (\#4970) were all purchased from Cell Signaling Technology (Beverly, MA, USA) and were prepared in 5\% BSA at a dilution of 1:1000. Then the membranes were incubated with HRP-conjugated secondary antibodies (Sigma-Aldrich) at a 1:5000 dilution for another $2 \mathrm{~h}$ at room temperature. ECL reagent (Beyotime Biotechnology) was used for development of signals.

\section{Statistical analysis}

All experiments were repeated three times. The results of multiple experiments are presented as the mean \pm SD. Statistical analyses were performed using Graphpad 6.0 statistical software (GraphPad Software, San Diego, CA, USA). The $P$-values were calculated using a one-way analysis of variance (ANOVA). A $P$-value of $<0.05$ was considered to indicate a statistically significant result.

\section{Results}

LPS induced cell apoptosis and inflammation in PC12 cells

As shown in Fig. 1A, exposure of PC12 cells to $1 \mu \mathrm{g} / \mathrm{ml}$ LPS for $12 \mathrm{~h}$ did not affect cell viability. However, 5 and $10 \mu \mathrm{g} / \mathrm{ml}$ exposure significantly decreased cell viability by approximately 55\% and 48\%, respectively (both $P<0.01$ ). As shown in Fig. 1 B and 1 C, 5 and $10 \mu \mathrm{g} / \mathrm{ml}$ LPS significantly increased apoptotic cell rate $(P<0.05$ or $P<0.01)$, while down-regulated Bcl-2, up-regulated Bax, and cleaved caspase-3 and caspase-9. We further explored the effect of LPS on the expression of pro-inflammatory cytokines in PC12 cells. qRT-PCR (Fig. 1D) and western blot analysis (Fig. 1E) revealed that the expression levels of IL-1 $\beta$, IL-6, IL-8, and TNF- $\alpha$ were all remarkably increased following LPS exposure at 5 
and $10 \mu \mathrm{g} / \mathrm{ml}(P<0.001)$. For the following experiments, $5 \mu \mathrm{g} / \mathrm{ml}$ was selected as a LPSstimulating condition.

\section{CAP pretreatment attenuated LPS-induced cell injuries in PC12 cells}

We further investigated the influence of CAP on PC12 cell injuries induced by LPS. CCK-8 assay demonstrated that pretreatment of PC12 cells with 100 and $200 \mu \mathrm{g} / \mathrm{mlCAP}$ significantly attenuated LPS-induced viability inhibition (both $P<0.01$ ) (Fig. 2A). Also, 100 and 200 $\mu \mathrm{g} / \mathrm{ml}$ CAP significantly repressed LPS-induced apoptosis, as evidenced by the declined apoptotic cell rate $(P<0.01)$ (Fig. 2B), the up-regulated Bcl-2, and the down-regulated Bax, cleaved caspase- 3 and cleaved caspase-9 (Fig. 2C). Fig. 2D showed that, the mRNA levels of IL-1 $\beta$, IL-6, IL-8, and TNF- $\alpha$ were significantly declined with CAP pretreatment $(P<0.05, P$ $<0.01$ or $P<0.001$ ). Similar results were observed in protein expression levels of these proinflammatory cytokines (Fig. 2E).

\section{CAP suppressed COX-1 expression}

COX-1 appears to play a critical in the inflammation response of SCI [17]. Thus, we explored the modulation of CAP on COX-1 expression. As shown in Fig. 3A, when treated with $100 \mu \mathrm{g} / \mathrm{ml}$ of CAP alone, the mRNA level of COX-1 was significantly inhibited compared with control group $(P<0.01)$. Meanwhile, CAP pretreatment reversed the up-regulating effect of LPS on COX-1 expression $(P<0.01)$ (Fig. 3A). Similar regulation was observed in protein levels of COX-1 (Fig. 3B).

\section{CAP pretreatment attenuated LPS-induced cell injuries through down-regulation of COX-1 \\ To investigate the} involvement of COX-1 in CAPmediated cell apoptosis and inflammation in LPS-injured cell, COX-1 expression in PC12 cells was overexpressed by transfection with COX1 expressing vector (pEXCOX-1). qRT-PCR and western blot analytical results indicated that, the mRNA and protein levels of COX-1 were significantly elevated after pEX-COX-1 transfection $(P$ $<0.01$ ) (Fig. 4A). Fig. 4B-4F showed that, overexpression of COX-1 blocked the protective effects of CAP on LPS-injured PC12 cells, as COX1 overexpression significantly declined cell viability $(P<$ 0.05) (Fig. 4B), promoted apoptotic cell rate $(P<0.05)$ (Fig. 4C), up-regulated Bax, cleaved caspase- 3 and cleaved caspase-9, down-regulated Bcl-2 (Fig. 4D), and increased the expression of proinflammatory cytokines (all $P$ $<0.01$ ) (Fig. 4E and 4F).

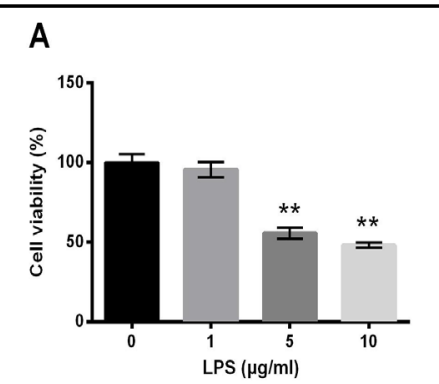

C

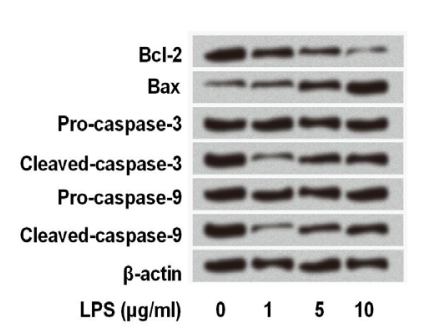

E

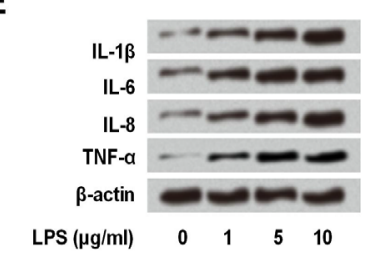

Fig. 1. LPS induced cell apoptosis and inflammation in PC12 cells. PC12 cells were treated with LPS in a series of concentration $(1,5$, and $10 \mu \mathrm{g} / \mathrm{ml}$ ) for $12 \mathrm{~h}$. (A) Cell viability was measured by CCK-8 assay kit. (B) Apoptotic cell rate was assessed by flow cytometry assay. (C) The expression of apoptosis-related factors was measured by western blot. (D) The mRNA and (E) protein levels of proinflammatory cytokines were analyzed by qRT-PCR and western blot. $* \mathrm{P}<0.05,{ }^{* *} \mathrm{P}<0.01,{ }^{* * *} \mathrm{P}<0.001$.

\section{KARGER}




\section{CAP activated PI3K/AKT pathway through down-regulation of COX-1}

PI3K/AKT pathway has been identified as an important regulator in the pathogenesis of SCI [22]. Here, we explored whether the PI3K/AKT signaling pathway was regulated by CAP in PC12 cells. As shown in Fig. 5, PI3K/AKT pathway was activated in PC12 cells after exposure to $5 \mu \mathrm{g} / \mathrm{ml}$ LPS, as the phosphorylation levels of PI3K and AKT were remarkably increased. As expected, CAP $(100 \mu \mathrm{g} / \mathrm{ml})$ further increased the expression of p-PI3K and p-AKT. However, the regulatory effects of CAP on p-PI3K and p-AKT expression were reversed by COX-1 overexpression.

Fig. 2. CAP treatment attenuated LPS-induced cell injuries in PC12 cells. PC12 cells were pretreated with various concentrations of CAP (10, 100 and $200 \mu \mathrm{g} / \mathrm{ml}$ ) for $24 \mathrm{~h}$ before the addition of LPS $(5 \mu \mathrm{g} / \mathrm{ml})$ for 12 h. (A) Cell viability, (B) apoptotic cell rate, and (C) the expression of apoptosis-related proteins were respectively assessed by CCK-8 assay, flow cytometry, and western blot. (D) The mRNA and (E) protein levels of pro-inflammatory cytokines were assessed by qRT-PCR and western blot. ${ }^{*} \mathrm{P}<0.05,{ }^{* *} \mathrm{P}<0.01,{ }^{* * *} \mathrm{P}$ $<0.001$.
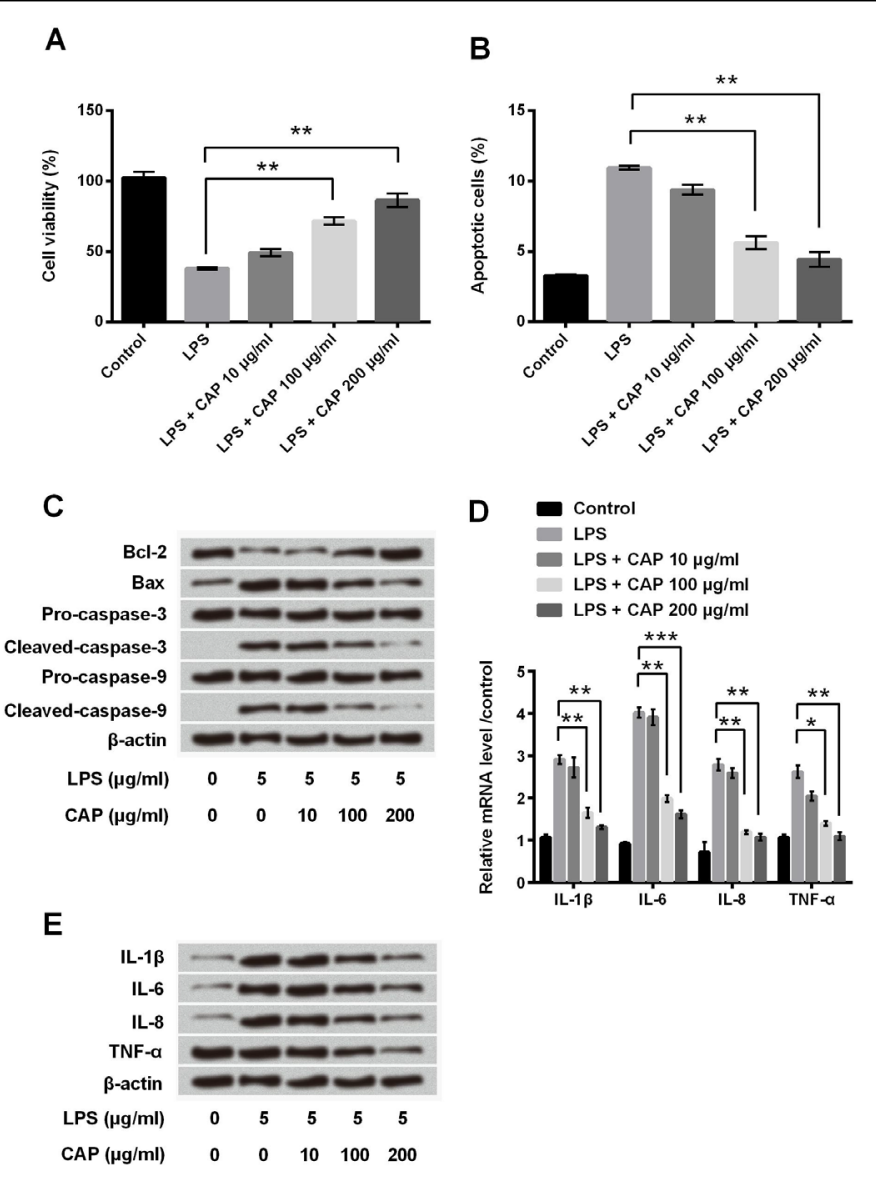

Fig. 3. CAP suppressed COX1 expression. PC12 cells were pretreated with $100 \mu \mathrm{g} / \mathrm{ml}$ CAP for $24 \mathrm{~h}$ alone, or followed by LPS ( $5 \mu \mathrm{g} /$ $\mathrm{ml}$ ) for another $12 \mathrm{~h}$. (A) The mRNA and (B) protein levels of COX-1 were analyzed by qRT-PCR and western blot. ${ }^{* *} \mathrm{P}<0.01$.

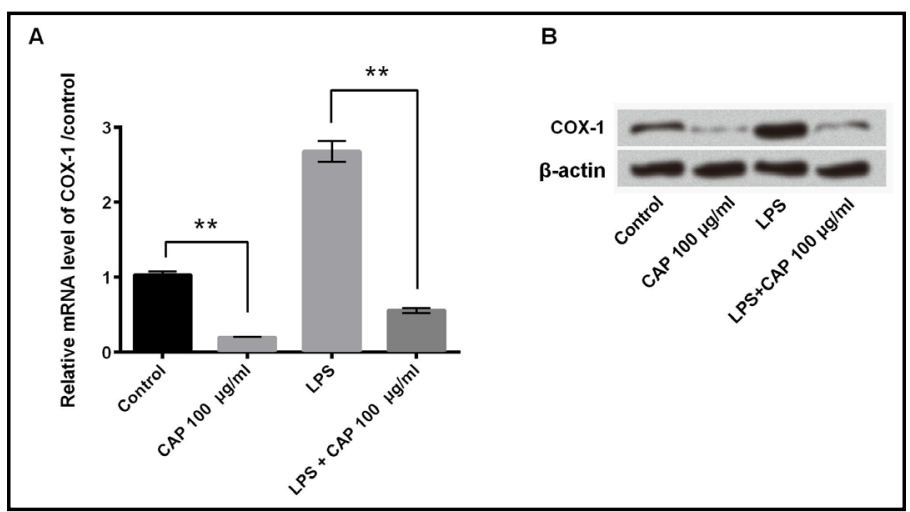


Fig. 4. CAP treatment attenuated LPS-induced cell injuries through down-regulation of COX-1 expression. Non-transfected cells, and cells transfected with pEX or pEX-COX-1 were pretreated with CAP $(100 \mu \mathrm{g} / \mathrm{ml})$ before the addition of LPS $(5 \mu \mathrm{g} / \mathrm{ml})$ for another $12 \mathrm{~h}$. (A) The efficiency of transfection was performed by qRT-PCR and western blot. (B) Cell viability, (C) apoptotic cell rate, and (D) the expression of apoptosisrelated proteins were respectively assessed by CCK-8 assay, flow cytometry, and western blot. (E) The mRNA and (F) protein levels of pro-inflammatory cytokines were measured by qRT-PCR and western blot. * $\mathrm{P}<0.05$, ** $\mathrm{P}<0.01$.

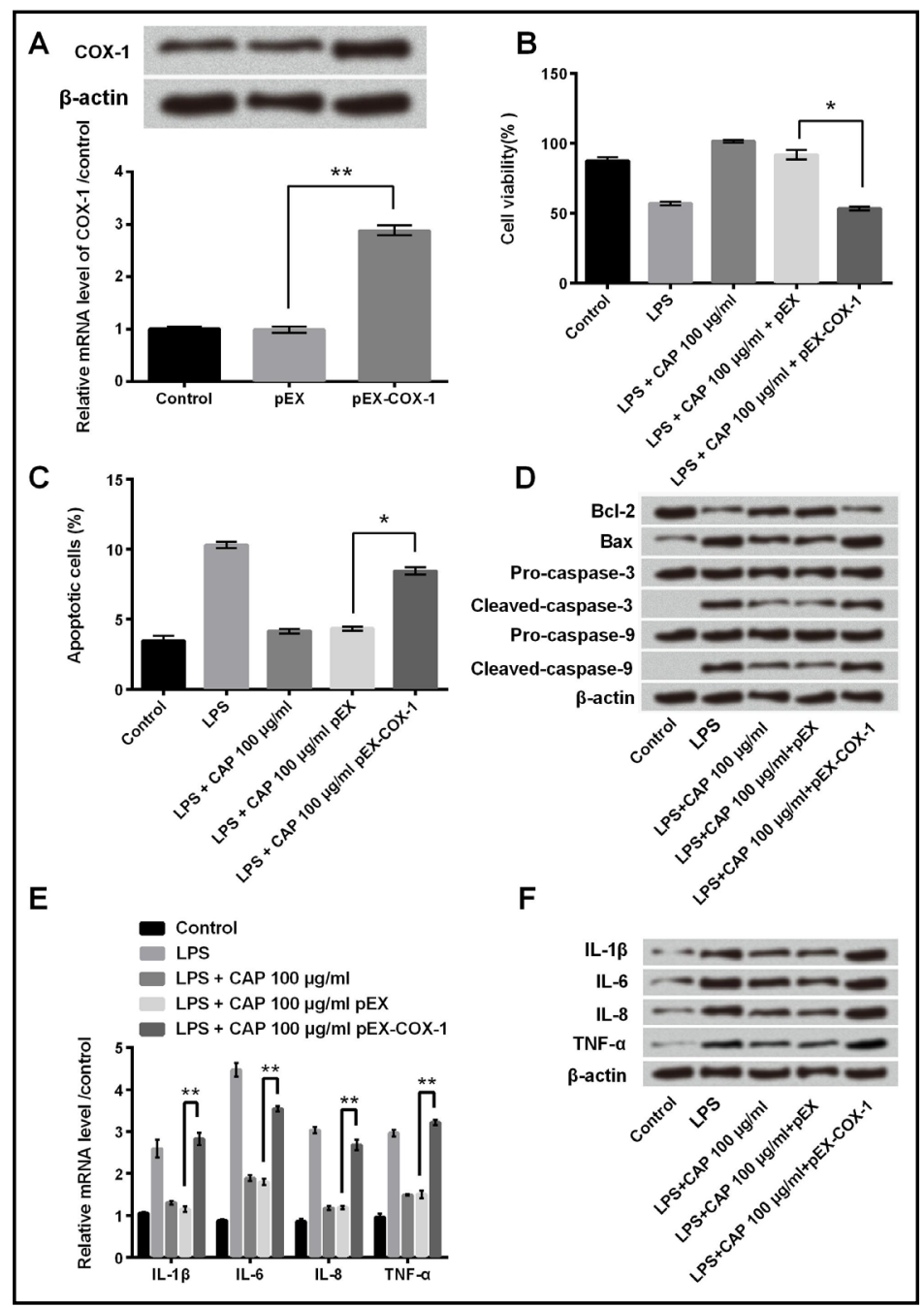

Fig. 5. CAP activated PI3K/ AKT pathway through down-regulation of COX1. Non-transfected cells, and cells transfected with pEX or pEX-COX-1 were pretreated with CAP (100 $\mu \mathrm{g} / \mathrm{ml}$ ) before the addition of LPS (5 $\mu \mathrm{g} / \mathrm{ml})$ for another $12 \mathrm{~h}$. The protein expression levels of PI3K, p-PI3K, AKT and p-AKT were detected by western blot in PC12 cells.

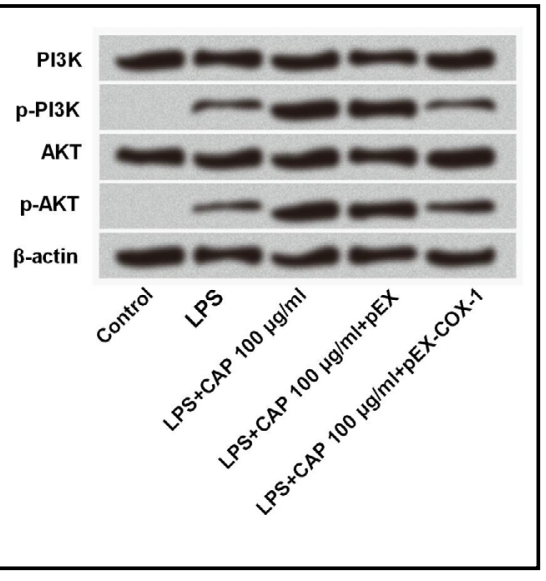
[14]. For example, angelica sinensis polysaccharides inhibit endothelial progenitor cell senescence through the reduction of oxidative stress and activation of the AKT/hTERT pathway [27]. And it also suppresses cell growth and cell metastasis in human lung adenocarcinoma A549 cells by regulating MMPs/TIMPs and TGF- $\beta 1$ [23]. Moreover, CAP protects immunological colon injury induced by TNBS and ethanol enema in rats probably due to the mechanism of anti-oxidation, anti-inflammation, immunomodulation and 


\section{Cellular Physiology Cell Physiol Biochem 2018;49:1380-1388 \begin{tabular}{l|l} 
DOI: 10.1159/000493415 & $\begin{array}{l}\text { O 2018 The Author(s). Published by S. Karger AG, Basel } \\
\text { www.karger.com/cpb }\end{array}$
\end{tabular} \\ Xie et al.: The Role of CAP in LPS-Injured PC12 Cells}

promotion of wound repair [28]. In agreement with previous studies showing that angelica sinensis reduces inflammatory reaction as well as apoptosis in SCI model in vivo $[14,15]$, the present study demonstrated that CAP increased cell viability, and reduced apoptosis and the expression of pro- inflammatory cytokines in LPS-injured PC12 cells.

Inflammation as well as apoptosis play vital roles in the secondary damage of SCI and increase the extent of pathological implications [29]. Increased production of proinflammatory cytokines, such as TNF-a, IL-1 $\beta$, IL-6 and IL-8, play a pivotal role in triggering the development of SCI. Our results revealed that the expression of these core pro-inflammatory cytokines was significantly increased in PC12 cells after LPS $(5 \mu \mathrm{g} / \mathrm{ml})$ exposure for $12 \mathrm{~h}$. However, CAP pretreatment remarked declined the expression of these cytokines, which indicated the anti-inflammatory effect of CAP.

Previous studies have shown that apoptosis, which is associated with the regulation of Bcl-2 protein family and the activation of caspases [30,31], is an important event in the secondary injury following SCI $[32,33]$. In addition, apoptosis participates in secondary degenerative damage, and eventually results in the functional disability of the spinal cord below the injured area [34]. Our results showed that CAP could significantly reduce apoptotic cell rate and regulate apoptosis-related factors in LPS-injured PC12 cells, which indicated the anti-apoptotic effect of CAP.

Recently, it has been reported that the PI3K/AKT signaling pathway not only plays an important role in cell survival, apoptosis and protein synthesis, but also in negative regulation of LPS-induced acute inflammatory responses both in vitro and in vivo [35]. And the PI3K/AKT signaling pathway is involved in the SCI and is closely related to cell apoptosis [22]. We found that CAP reduced the expression of COX-1, which was increased by LPS treatment. COX-1 overexpression reversed the protective effects of CAP on LPSinjured PC12 cells. Additionally, we found that overexpression of COX-1 deactivated PI3K/ AKT pathway, indicating CAP activated PI3K/AKT through down-regulation of COX-1. These results suggested that CAP may attenuate LPS-induced injuries through down-regulation of COX-1 and activation of PI3K/AKT pathway in PC12 cells. And also, this study demonstrated that COX-1 expression altered the expression of p-PI3K and p-AKT, but not the total levels of PI3K and AKT. Thus we inferred that COX-1 regulated PI3K/AKT pathway might be via PTEN. Actually, a previous study has reported that COX-2, another kind of COXs with similar structure of COX-1, impacted the activation of PI3K/AKT pathway via modulation of PTEN [36]. Further investigation which focused on the regulatory relationship between COX-1 and PTEN may be helpful for the better understanding of how COX-1 regulates the PI3K/AKT pathway.

\section{Conclusion}

The present study demonstrated that CAP alleviated LPS-induced inflammation and apoptosis in PC12 cells and the mechanism may be through inhibition of COX-1 and activation of PI3K/AKT signaling pathway. These findings provided in vitro evidence that application of CAP might be an effective treatment for SCI in the future. This study might be helpful for further understanding of the pathophysiological mechanisms of SCI and developing the targeted therapies for SCI.

\section{Disclosure Statement}

The authors declare to have no competing interests.

\section{References}

1 Chen Y, Tang Y, Allen VE, Devivo M: Fall-Induced Spinal Cord Injury: External Causes and Implications for Prevention. Arch Phys Med Rehab 2015;96:e20-e20.

-2 Thuret S, Moon LD, Gage FH: Therapeutic interventions after spinal cord injury. Nat Rev Neurosci 2006;7:628-643. 


\section{Cellular Physiology Cell Physiol Biochem 2018;49:1380-1388 \begin{tabular}{l|l|l} 
and Biochemistry $10.1159 / 000493415$ & $\begin{array}{l}\text { D) } 2018 \text { The Author(s). Published by S. Karger AG, Basel } \\
\text { www.karger.com/cpb }\end{array}$ \\
\hline
\end{tabular}

3 Esposito E, Paterniti I, Mazzon E, Genovese T, Di PR, Galuppo M, Cuzzocrea S: Effects of palmitoylethanolamide on release of mast cell peptidases and neurotrophic factors after spinal cord injury. Brain Behav Immun 2011;25:1099-1112.

4 Dvorak MF, Noonan VK, Fallah N, Fisher CG, Finkelstein J, Kwon BK, Rivers CS, Ahn H, Paquet J, Tsai EC: The Influence of Time from Injury to Surgery on Motor Recovery and Length of Hospital Stay in Acute Traumatic Spinal Cord Injury: An Observational Canadian Cohort Study. J Neurotraum 2015;32:645.

5 Kwon BK, Okon EB, Plunet W, Baptiste D, Fouad K, Hillyer J, Weaver LC, Fehlings MG, Tetzlaff W: A systematic review of directly applied biologic therapies for acute spinal cord injury. J Neurotraum 2011;28:1589-1610.

6 Kwon BK, Okon E, Hillyer J, Mann C, Baptiste D, Weaver LC, Fehlings MG, Tetzlaff W: A systematic review of non-invasive pharmacologic neuroprotective treatments for acute spinal cord injury. J Neurotraum 2011;28:1545-1588.

7 PhD N-KLM, Yi PZ, Titsworth WL, Xiaoyan Jiang MD, Shu H, Pei-Hua Lu MD, Shields CB, Xu XM: A novel role of phospholipase A 2 in mediating spinal cord secondary injury. Ann Neurol 2010;59:606-619.

-8 Genovese T, Esposito E, Mazzon E, Di Paola R, Caminiti R, Bramanti P, Cappelani A, Cuzzocrea S: Absence of endogenous interleukin-10 enhances secondary inflammatory process after spinal cord compression injury in mice. J Neurochem 2009;108:1360-1372.

-9 Shen LF, Cheng H, Tsai MC, Kuo HS, Chak KF: PAL31 may play an important role as inflammatory modulator in the repair process of the spinal cord injury rat. J Neurochem 2009;108:1187-1197.

10 Qin T, Chen J, Wang D, Hu Y, Wang M, Zhang J, Nguyen TL, Liu C, Liu X: Optimization of selenylation conditions for Chinese angelica polysaccharide based on immune-enhancing activity. Carbohyd Polym 2013;92:645-650.

11 Chen XP, Wei LI, Xiao XF, Zhang LL, Liu CX: Phytochemical and pharmacological studies on Radix Angelica sinensis. Chin J Nat Medicine 2013;11:577-587.

12 Han SB, Kim YH, Chang WL, Sun MP, Lee HY, Ahn KS, Kim IH, Kim HM: Characteristic immunostimulation by angelan isolated from Angelica gigas Nakai. Immunopharmacol 1998;40:39-48.

13 Jeon YJ, Kim HM: Experimental evidences and signal transduction pathways involved in the activation of NF-kappa B/Rel by angelan in murine macrophages. Int Immunopharmacol 2001;1:1331-1339.

14 Xu J, Xiaoqiang E, Liu HY, Tian J, Yan JL: Angelica Sinensis attenuates inflammatory reaction in experimental rat models having spinal cord injury. Int J Clin Exp Pathol 2015;8:6779-6785.

15 Ying XZ, Zhu B, Zheng Q, Shi SY, Wang YF, Shen J, Zhang MF, Zhang KF: Angelica Sinensis restores motor function and reduces inflammation as well as apoptosis in CD1 mice with spinal cord injury. Int J Clin Exp Medicine 2016;9:5602-5608.

16 Khan AA, Iadarola M, Yang HYT, Dionne RA: Expression of COX-1 and COX-2 in a Clinical Model of Acute Inflammation. J Pain 2007;8:349-354.

17 Schwab JM, Brechtel K, Nguyen TD, Schluesener HJ: Persistent accumulation of cyclooxygenase-1 (COX1) expressing microglia/macrophages and upregulation by endothelium following spinal cord injury. J Neuroimmunol 2000;111:122-130.

18 Zhu X, Eisenach JC: Cyclooxygenase-1 in the spinal cord is altered after peripheral nerve injury. Anesthesiology 2003;99:1175.

19 Cheong CU, Yeh CS, Hsieh YW, Lee YR, Lin MY, Chen CY, Lee CH: Protective Effects of Costunolide against Hydrogen Peroxide-Induced Injury in PC12 Cells. Molecules 2016;21: pii: E898. doi: 10.3390/ molecules21070898.

20 Tian R, Shi R: Dimercaprol is an acrolein scavenger that mitigates acrolein-mediated PC-12 cells toxicity and reduces acrolein in rat following spinal cord injury. J Neurochem 2017;141:708-720.

21 Guo Y, Niu S: MiR-25 protects PC-12 cells from H2O2 mediated oxidative damage via WNT/beta-catenin pathway. J Spinal Cord Med 2018;41:416-425.

-22 Zhang P, Zhang L, Zhu L, Chen F, Zhou S, Tian T, Zhang Y, Jiang X, Li X, Zhang C: The change tendency of PI3K/Akt pathway after spinal cord injury. Am J Transl Res 2015;7:2223.

23 Gao M, Zhang JH, Zhou FX, Xie CH, Han G, Fang SQ, Zhou YF: Angelica sinensis suppresses human lung adenocarcinoma A549 cell metastasis by regulating MMPs/TIMPs and TGF- $\beta 1$. Oncol Rep 2012;27:585593.

24 Yang C, Niu S, Yu L, Zhu S, Zhu J, Zhu Q: The aqueous extract of Angelica sinensis, a popular Chinese herb, inhibits wear debris-induced inflammatory osteolysis in mice. J Surg Res 2012;176:476-483.

25 Chao WW, Hong YH, Chen ML, Lin BF: Inhibitory effects of Angelica sinensis ethyl acetate extract and major compounds on NF-kappaB trans-activation activity and LPS-induced inflammation. J Ethnopharmacol 2010;129:244-249.

-26 Yang T, Jia M, Meng J, Wu H, Mei Q: Immunomodulatory activity of polysaccharide isolated from Angelica sinensis. Int J Biol Macromol 2006;39:179. 


\section{Cellular Physiology Cell Physiol Biochem 2018;49:1380-1388 \begin{tabular}{ll|l} 
DOI: 10.1159/000493415 & $\begin{array}{l}\text { O 2018 The Author(s). Published by S. Karger AG, Basel } \\
\text { www.karger.com/cpb }\end{array}$ \\
\hline
\end{tabular}}

-27 Lai P, Liu Y: Angelica sinensis polysaccharides inhibit endothelial progenitor cell senescence through the reduction of oxidative stress and activation of the Akt/hTERT pathway. Pharm Biol 2015;53:1842-1849.

-28 Shao-PingLiu, Wei-GuoDong, Dong-FangWu, He-ShengLuo, Jie-PingYu, HubeiProvince: Protective effect of angelica sinensis polysaccharide on experimental immunological colon injury in rats. World J Gastroentero 2003;9:2786-2790.

-29 Lu J, Ashwell KW, Waite P: Advances in secondary spinal cord injury: role of apoptosis. Spine 2000;25:1859-1866.

-30 Adrain C, Creagh EM, Martin SJ: Apoptosis-associated release of Smac/DIABLO from mitochondria requires active caspases and is blocked by Bcl-2. Embo J 2001;20:6627-6636.

31 Elmore S: Apoptosis: A Review of Programmed Cell Death. Toxicol Pathol 2007;35:495-516.

-32 Emanuela E, Emanuela M, Irene P, Daniela I, Placido B, Salvatore C: Olprinone Attenuates the Acute Inflammatory Response and Apoptosis after Spinal Cord Trauma in Mice. Plos One 2010;5:e12170.

-33 Liu XZ, Xu XM, Hu R, Du C, Zhang SX, Mcdonald JW, Dong HX, Wu YJ, Fan GS, Jacquin MF: Neuronal and glial apoptosis after traumatic spinal cord injury. J Neurosci 1997;17:5395.

-34 Xin Y, Yue Y, Cao FL, Chen YF, Ye P, Hou WG, Sun SK, Luo ZJ: Tanshinone IIA Attenuates the Inflammatory Response and Apoptosis after Traumatic Injury of the Spinal Cord in Adult Rats. Plos One 2012;7:e38381.

35 Xu CQ Liu BJ, Wu JF, Xu YC, Duan XH, Cao YX, Dong JC: Icariin attenuates LPS-induced acute inflammatory responses: Involvement of PI3K/Akt and NF-אB signaling pathway. European J Pharmacol 2010;642:146153.

-36 Li CJ, Chang JK, Wang GJ, Ho ML: Constitutively expressed COX-2 in osteoblasts positively regulates Akt signal transduction via suppression of PTEN activity. Bone 2011;48:286-297. 